\title{
Necrosis de glande secundaria a uretrectomía por recidiva tumoral de un carcinoma transicional de alto grado
}

\author{
Álvarez Múgica M, Jalón Monzón A, González Álvarez RC, Fernández Gómez JM, \\ Martín Benito JL, Regadera Sejas FJ.
}

Servicio de Urología 1. Hospital Universitario Central de Asturias. Oviedo. Asturias.

Actas Urol Esp. 2007;31(2):178

$\mathrm{P}$ aciente de 78 años operado en junio del 2004 de cistoprostatectomía radical más derivación cutánea por carcinoma transicional de alto grado en vejiga. Biopsias en uretra prostáticas pre-cirugía resultaron negativas para tumor. 10 meses después de la cirugía comenzó con uretrorragia detectándose recidiva tumoral en uretra bulbomembranosa, por lo que se le realizó uretrectomía. En el postoperatorio inmediato, (6º día tras la cirugía), comenzó la aparición de una escara necrótica en la punta del glande que aumentó de tamaño en los días posteriores (Figs. 1 y 2). Se le practicó glandectomía por necrosis del glande (Fig. 3).

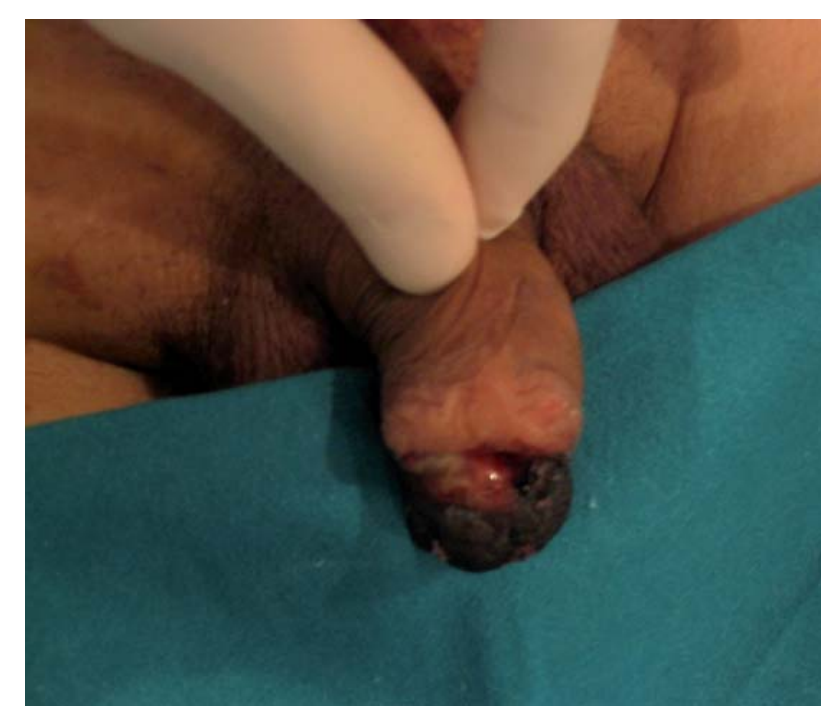

FIGURA 1

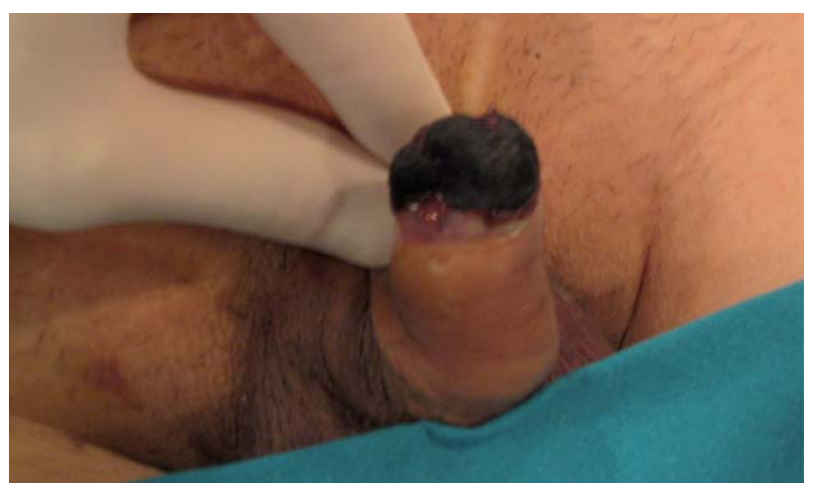

FIGURA 2

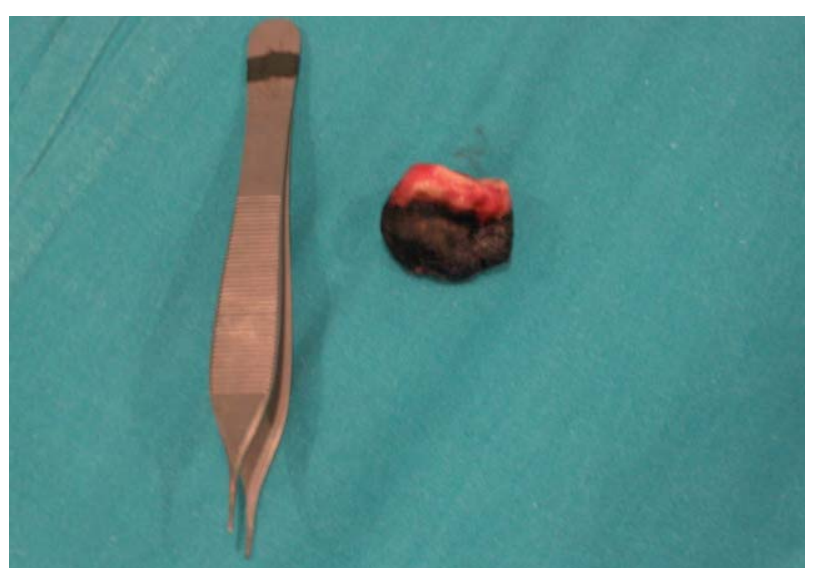

FIGURA 3

Correspondencia autor: Dr. M. Álvarez Múgica

Servicio de Urología 1. Hospital Universitario Central de Asturias. Celestino Villamil s/n. 33006. Oviedo. Asturias.

Tel.: 985108000 (extensión 38143)

E-mail: malvarez79@mixmail.com

Información artículo: Imágenes en Urología

Trabajo recibido: enero 2006

Trabajo aceptado: marzo 2006 